\section{Higher Education in Hong Kong: Two Years Later}

\section{Grace C. L. Mak}

Grace C. L. Mak is on the faculty at the Hong Kong Institute of Education. Address: Hong Kong Institute of Education, 10 Lo Ping Rd., Tai Po, New Territories, Hong Kong.

$\mathrm{H}$ igher education in Hong Kong has undergone two major phases of change in recent years. The first started in the mid- to late 1980s, spurred on by the drive for efficiency and the expansion of a previously elitist system; the second was marked by the return of Hong Kong's sovereignty to China in 1997. This article describes higher education in Hong Kong two years on. The current situation is a convergence of internal systemic development, the China factor, and the recent economic downturn.

\section{Academic Freedom}

Prior to the handover there was much anxiety about academic freedom in Hong Kong under China. As it turned out, there has been little significant change in autonomy in university governance and research. The tension between pro-Beijing and pro-West sentiments in society created by the political transition and the incidents that indicate Beijing's increasing influence over Hong Kong affairs has not been as apparent in academe, although this may change. Self-censorship may be found on an individual basis but is not a general collective phenomenon.

The relative calm over the issue of academic freedom may be due in part to Beijing's effort to honor Hong Kong' s autonomy and in part to the eclipse by more pressing demands from micro-level developments. The efficiency drive that is an international trend reached Hong Kong in the late 1980s and now has a tight grip on institutional life. Institutional productivity is under close scrutiny. For the faculty this means high expectations for teaching and research, winning grants, and professional and community service. Of these, research output is of primary importance.

Publication in international scholarly journals is generally assigned greater weight than publication in local ones. This has posed a dilemma for academics in culturally oriented fields in the social sciences and humanities. One criterion for awarding research grants is local relevance, yet the distribution of research output in nonlocal channels is more favorably rated. For academics in culturally bound fields these criteria are at times hard to reconcile. The overriding importance of research, despite the rhetoric about equal importance of teaching, has left teaching faculty torn between the two roles. Although equal attention should be devoted to the two roles, many cope by attending to research, often at the expense of teaching. While there is general agreement on the value of course evaluations in monitoring teaching, their side effects are also noted. Anxiety over evaluations has led some faculty members to appease students.

\section{Tensions}

This new emphasis on research and publication has created tensions between faculty and administrators. The tensions stem from the differential expectations for the university between two different types of academics-cultural professionals and corporatist administrators. Some academics are still ill adjusted to the research university in this age of pragmatism, especially those who studied or taught in Hong Kong's universities in the more relaxed, idiosyncratic era prior to 1980, when the institutions were teaching universities. Also, academics who view the university as performing broader cultural and social missions lament its increasingly narrow vocational function.

Higher education institutions must now prove their worth to the public. The new accountability challenge, together with the growth in size of the sector, has changed the relationship between the institutions and the community. Once few in number and esoteric, institutions of higher education are now very much a part of the community. The presence of education pages as a regular feature in each major local newspaper indicates the extent of general public interest in education. The press has also become a forum for news and views on higher education.

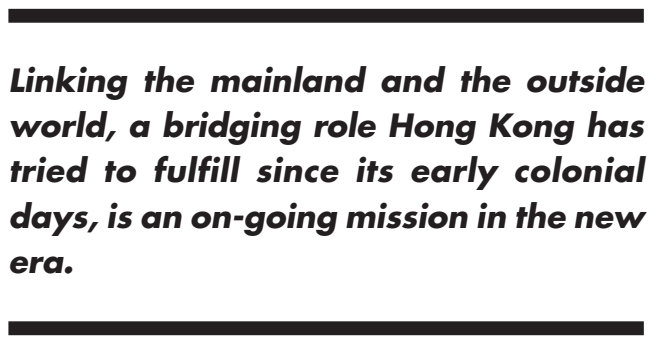

The recent economic gloom has intensified the stress within higher education. Funding for higher education has declined by 10 percent for 1998-2001, and a further cutback is under discussion. Public funding for higher education relative to expenditures in education has changed too. The public funding for higher education institutions under the aegis of the University Grants Committee has increased in absolute terms, from H.K. $\$ 8,157$ million in 1992-1993 to H.K.\$14,001 million in 1998-99, but has declined as a percentage of total expenditure in education from 36.9 percent to 27.5 percent during the same years. Academic salaries are linked to those of civil servants. There is much discussion about, and apparently support for, pay cuts for civil servants. Pay cuts for university staff look imminent as well. Another way to cope with a precarious bud- 
get is to hire new staff on contract terms. Thus, the security that used to be associated with academic work is gradually eroding. It appears that the issues facing Hong Kong higher education are part of a broader worldwide transformation of higher education, despite local and cultural variations.

The content of internationalism has also changed since the 1980s. Before, internationalism meant a heavy Western orientation, especially toward the major English-speaking countries. The boom in the economy in the 1980s and a collective awareness of an Asian identity fostered regional cooperation. Exchanges among Asian countries have flourished over the years. Common intellectual roots in graduate studies in the West provided an impetus for such exchanges, which have extended to academics who are wholly trained in indigenous institutions. Hong Kong academics' knowledge of English has facilitated such exchanges. Exchanges with the Chinese mainland are also thriving. At any one time there are dozens of visiting academics from mainland institutions in each institution in Hong Kong. Many Hong Kong academics conduct research related to China. The mainland has a solid tradition in science and technology and in some areas of the humanities. In comparison, the mainland is relatively unfamiliar with Western social science. Western-educated Hong Kong academics have a significant role to play in this phase of knowledge exchange between the two places. Linking the mainland and the outside world, a bridging role Hong Kong has tried to fulfill since its early colonial days, is an ongoing mission in the new era.

\section{Access to Higher Education in Bangladesh: The Case of Dhaka University}

\section{Munir Quddus}

Munir Quddus is professor of economics at the University of Southern Indiana, Evansville, Indiana, USA. E-mail: <mquddus@usi.edu>.

$I^{n}$ n 1997, Bangladesh had a per capita GNP of $\$ 270$ (ranked 116th in the world by the World Bank). With a life expectancy of 58 years, 81 percent of the population living in the countryside, and 42.7 percent living below the poverty line, this nation of 124 million people faces many challenges in the coming century.

The policy implications of equity in higher educationdefined as equality of access-are much debated today. Should the state increase spending on public universities? Should the government allow more private universities? Should there be taxpayer support for private universities? In Bangladesh, a popular view held by some academics and politicians is that the constitution requires the state to ensure equality of access at all levels of education. This group desires removal of all barriers to education. There is some concern that access to higher education has become less equitable in recent years. Figures from the country's fifth Five-Year-Plan underscore some of the inequities in higher education. For example, the gender ratio is 69:31 in favor of males. The geographic concentration index for higher education in urban areas is 0.97 , compared to 0.57 for secondary education, and 0.31 for primary education. An increasingly larger segment of the student population in the best public universities is coming from a small group of urban preparatory schools to which only the richer families can afford to send their children. ${ }^{1}$

The debate over access to higher education has sharp- ened since 1993, when for the first time private universities were allowed to operate in Bangladesh. Many critics believe that private universities are elitist and expensive, making them inappropriate in a poor society. According to this view, the existence of private universities will exacerbate the problem of inequitable access to higher education. On the other side of the debate, supporters of the private universities argue that in the long run private universities will improve access for economically disadvantaged students. They point out that the 1992 Private University Act requires that at least 5 percent of the student body receive full tuition waivers, which are intended to help poor students take advantage of these institutions. Additionally, the choice of a private university by students from rich families may possibly create vacancies in the public universities for poor students. Therefore, proponents reason, an expansion of private universities would improve access to tertiary education for all students. Critics disagree with these arguments, pointing out that the policies of private universities are not closely monitored by an outside independent body. Although private universities have increased diversity and choice for many students, their impact on access and equity is less clear.

\section{Dhaka University}

A random survey of 56 students at Dhaka University (DU) that I conducted in April 1999 highlighted certain issues concerning access to a public university education. Most of the 56 students state that they come from urban families. In fact, more than half gave permanent addresses in Dhaka, the capital city where the university is located. These findings would seem to support the claim that students from rural households (81 percent of the population) face difficulties in gaining access to the best public higher education institutions. Admission to DU, widely regarded as the country's premier university, has become increasingly difficult. In 1995 , only 3,730 out of 63,313 applicants to DU 